\title{
Populasi Optimum Sorgum Manis sebagai Hijauan Pakan Ternak dengan Pengaturan Populasi Tanaman
}

\author{
(Optimum Population of Sweet Sorghum Plants for Livestock Forage)
}

\author{
Suwarti, Efendi R, Pabendon MB \\ Balai Penelitian Tanaman Serealia, Jl. Dr. Ratulangi 274, Maros, Sulawesi Selatan \\ warti.smile@gmail.com
}

\begin{abstract}
Sweet sorghum is an alternative feed for livestock which contains several necessary nutrients The purpose of this study was to determine optimum population of sweet sorghum variety Super 1 , Super 2 and Numbu for livestock feed. Eksperiment was held on Maros Research Station ICERI on August-December 2016. Research design was split-plot design with three replication. The main plot were six rows spacing $(60 \times 10,60 \times 15,60 \times 20,70 \times 10,70 \times 15$, and $70 \times 20 \mathrm{~cm})$, and the subplot were three sweet sorghum varieties (Super 1, Super 2, and Numbu). The result of this study showed, interaction within row spacing and varieties was not significantly different for all variables. The $70 \times 10,60 \times 10$, and $70 \times 15 \mathrm{~cm}$ row spacing were produced biggest tonnase biomass $(13,26-15,19$ ton/ha) compared to other row spacing at 70 days after planting harvest time. All varieties produced the same biomass. High correlation of biomass and highly significant was derived from stem biomass and nira volume.
\end{abstract}

Key Words: Sorghum, Livestock, Feed

\begin{abstract}
ABSTRAK
Sorgum manis dapat menjadi salah satu alternatif pakan ternak yang mengandung berbagai nutrisi penting. Tujuan dari penelitian ini adalah untuk menentukan populasi optimum tanaman sorgum manis varietas Super 1, Super 2 dan Numbu sebagai pakan ternak. Percobaan dilaksanakan di Kebun Percobaan Balitsereal Maros pada bulan Agustus-Desember 2016 dengan pengambilan sampel brangkasan pada umur 70 hari setelah tanam. Desain percobaan yang dipergunakan adalah Split-Plot dengan tiga ulangan. Petak utama adalah enam pengaturan jarak tanam $(60 \times 10,60 \times 15$, $60 \times 20,70 \times 10,70 \times 15$ dan $70 \times 20 \mathrm{~cm}$ ) dan anak petak berupa tiga varietas sorgum manis (Super 1 , Super 2 dan Numbu). Hasil penelitian menunjukkan, interaksi antara jarak tanam dan populasi tidak berbeda nyata pada semua variabel. Jarak tanam $70 \times 10,60 \times 10$ dan $70 \times 15 \mathrm{~cm}$ menghasilkan bobot biomassa brangkasan terbesar (13,26-15,19 ton/ha). Sedangkan ketiga varietas menghasilkan bobot brangkasan yang tidak berbeda. Korelasi yang tinggi dan sangat nyata dengan biomassa brangkasan, diperoleh pada bobot batang dan volume nira.
\end{abstract}

Kata Kunci: Sorgum, Ternak, Pakan

\section{PENDAHULUAN}

Hijauan sebagai pakan ternak ruminansia dibutuhkan hingga 10\% dari bobot ternak. Dengan jumlah populasi ternak ruminansia (sapi, kuda dan kerbau) pada tahun 2015 yang mencapai 17,7 juta (Pusdatin 2017), maka pemenuhan kebutuhan akan pakan hijauan berkualitas merupakan hal yang layak untuk diperhatikan. Produktivitas ternak yang tinggi dipengaruhi oleh kualitas pakan yang baik. Rendahnya produktivitas ternak terkait dengan ketersediaan pakan yang berfluktuasi dengan kualitas yang rendah (Haryanto 2009). Kualitas pakan ternak meliputi nutrisi dan tingkat konsumsi oleh ternak, sedangkan kuantitas pakan merupakan hasil pengukuran mekanis melalui pemotongan dan penimbangan (Abqoriyah et al. 2015). 
Budidaya sorgum manis (Sorghum bicolor L Moench) pada umumnya dilakukan untuk memperoleh nira sebagai bahan baku etanol maupun gula cair (Andrzejewski et al. 2013; Agung et al. 2013), selain juga dapat dimanfaatkan sebagai bahan baku butanol dan bahan campuran plastik kayu (Yu et al. 2012). Padahal, pemanfaatan tanaman sorgum sebagai pakan ternak memiliki peluang yang sangat terbuka, sebab kandungan nutrisi pada batang dan daun sorgum hampir setara dengan rumput Gajah yang sudah lebih dahulu populer sebagai bahan pakan ternak ruminansia (Irawan \& Sutrisna 2011). Biji sorgum dapat dimanfaatkan sebagai bahan pakan unggas dengan mempertimbangkan kandungan taninnya, bahkan dapat mensubtitusi penggunaan jagung pada ransum pakan ayam, itik, kambing, sapi dan babi tanpa menimbulkan efek samping (Irawan \& Sutrisna 2011). Sorgum manis merupakan tanaman biji-bijian alternatif yang dapat tumbuh di lingkungan dengan pengelolaan yang kurang optimal (Borghi et al. 2013). Tanaman ini toleran terhadap cekaman kekeringan maupun suhu tinggi serta memiliki daya adaptasi yang cukup luas (Sirappa 2003; Barcelos et al. 2016). Pada lingkungan kurang optimal dengan cekaman genangan air maupun kekeringan tanaman sorgum masih dapat berproduksi dengan baik (Barbanti et al. 2006; Capriyati et al. 2014). Pemanfaatan brangkasan tanaman sorgum manis sebagai pakan ternak telah dilakukan pada banyak daerah antara lain di Gunung Kidul (Yogyakarta) dan Nusa Tenggara Timur.

Biomassa sorgum mengandung $339 \mathrm{~g}$ selulosa, $375 \mathrm{~g}$ hemiselulosa, $162 \mathrm{~g}$ lignin dan $20 \mathrm{~g}$ abu dalam tiap kilogram bahan (Enciso et al. 2015). Abqoriyah et al. (2015) menyatakan kandungan protein dan mineral hijauan akan menurun sesuai umur tanaman, sedangkan kandungan serat kasar akan semakin meningkat. Jika dimanfaatkan daunnya saja, potensi sorgum sebagai pakan adalah 14-16\% dari total biomassa (Sirappa 2003). Pemanenan umur 70 hari setelah tanam (hst) dimaksudkan untuk memperoleh hijauan yang memiliki kandungan nutrisi tinggi, serat kasar yang rendah namun dengan jumlah bobot biomassa yang tinggi karena bagian batang masih bisa dimanfaatkan. Dinding sel bahan pakan pada tanaman hijauan berserat pada umumnya meningkat kadarnya seiring bertambahnya umur tanaman sehingga nilai neutral detergent fiber (NDF) dan acid detergent fiber (ADF) sebagai indikator kecernaan bahan pakan berupa hijauan harus diperhatikan dalam strategi formulasi pakan ternak (Sudirman et al. 2015). Tujuan dari penelitian ini adalah untuk mencari populasi optimum sorgum manis yang memiliki biomassa tertinggi sebagai pakan ternak.

\section{MATERI DAN METODE}

Penelitian dilaksanakan di Kebun Percobaan Maros pada bulan Agustus-Desember 2016. Percobaan menggunakan Rancangan Split Plot dengan tiga ulangan. Petak utama adalah tingkat kepadatan populasi tanaman per satuan luas petak yang sama, berupa P1: Jarak tanam $60 \times 10 \mathrm{~cm}=166.667$ tanaman $/ \mathrm{ha} ; \mathrm{P} 2$ : Jarak tanam $60 \times 15 \mathrm{~cm}=111.111$ tanaman/ha; P3: Jarak tanam $60 \times 20 \mathrm{~cm}=83.333$ tanaman/ha; P4: Jarak tanam 70 $\times 10 \mathrm{~cm}=$ 142.857 tanaman/ha; P5: Jarak tanam $70 \times 15 \mathrm{~cm}=95.238$ tanaman/ha; dan P6: Jarak tanam $70 \times 20 \mathrm{~cm}=71.429$ tanaman/ha. Anak petak adalah varietas sorgum manis yaitu Super-1, Super-2 dan Numbu. Terdapat 18 kombinasi percobaan yang diulang sebanyak tiga kali. Tiap kombinasi perlakuan ditanam pada petak seluas $5 \times 5 \mathrm{~m}$ sehingga luas seluruh kombinasi perlakuan adalah $1.350 \mathrm{~m}^{2}$.

Dosis pupuk NPK yang diberikan pada tiap tanaman adalah 112,5 kg N/ha, $100 \mathrm{~kg}$ $\mathrm{P} /$ ha dan $75 \mathrm{~kg} \mathrm{~K} / \mathrm{ha}$. Pemupukan diberikan dalam bentuk pupuk urea (sumber hara $\mathrm{N}$ ), dan Ponska (sumber hara N, P dan K). Pemberian pupuk dilaksanakan dua kali pada 10 dan 35 hst. Pada pemupukan pertama, diberikan setengah dosis $\mathrm{N}$ dan seluruh pupuk $\mathrm{P}$ serta K. Pemupukan kedua dilaksanakan untuk memberikan sisa pupuk N. Peubah yang 
diamati dalam penelitian ini meliputi tinggi tanaman, jumlah daun, panjang daun, diameter batang dan komponen panen 70 hst berupa bobot biomassa batang (t/ha), bobot biomas daun (t/ha) dan kadar gula nira batang (\% brix). Pengamatan dilaksanakan pada umur tanaman 30, 50 dan 70 hst. Pemanenan biomassa batang dilaksanakan pada umur tanaman 70 hst dengan cara mengambil sampel 2 baris $\times 4 \mathrm{~m}$ (11-12\% dari luasan lahan tiap plot). Pengukuran volume nira, kadar brix dan alkohol relatif dilakukan setelah batang dibersihkan, kemudian diperas menggunakan mesin pemeras batang sorgum. Data yang diperoleh dianalisis menggunakan program STAR dari IRISTAT.

\section{HASIL DAN PEMBAHASAN}

\section{Pengaruh varietas dan populasi sorgum manis serta interaksinya terhadap komponen hasil dan karakter agronomis}

Hasil analisis sidik ragam umur tanaman 30, 50 dan 70 hst (Tabel 1) menunjukkan interaksi antara varietas sorgum dengan populasi tanaman tidak berbeda nyata pada seluruh parameter pengamatan. Pada komponen hasil, populasi berpengaruh terhadap bobot brangkasan, bobot batang dan hasil nira. Hasil penelitian Berenguer \& Faci (2001) menyatakan pada pengairan yang cukup, perbedaan populasi tanaman sorgum tidak menunjukkan perbedaan hasil pada saat masak fisiologis. Varietas berpengaruh nyata pada kadar brix dan berpengaruh sangat nyata terhadap kadar alkohol relatif.

Pada umur tanaman $30 \mathrm{hst}$, populasi tanaman berpengaruh sangat nyata terhadap tinggi tanaman sorgum, namun tidak berpengaruh terhadap karakter yang lainnya. Sedangkan varietas tidak berpengaruh terhadap seluruh karakter yang diamati. Saat umur tanaman $50 \mathrm{hst}$, populasi tanaman berpengaruh nyata terhadap jumlah daun dan berpengaruh sangat nyata terhadap lebar daun, nilai soil plant analysis development (SPAD) serta diameter batang. Varietas berpengaruh nyata terhadap lebar daun dan diameter batang. Umur tanaman $70 \mathrm{hst}$, populasi berpengaruh nyata terhadap tinggi tanaman dan panjang daun, serta berpengaruh sangat nyata terhadap diameter batang. Varietas berpengaruh nyata terhadap diameter batang dan berpengaruh sangat nyata terhadap tinggi tanaman dan jumlah ruas. Perubahan pertumbuhan tanaman sorgum manis 30-70 hst menunjukkan, faktor lingkungan lebih dominan mempengaruhi pertumbuhan tanaman dibandingkan dengan genetiknya. Pada umur tanaman 70 hst, sorgum manis mulai memasuki fase generatif yang ditandai dengan munculnya bunga dan perkembangan tanaman sudah optimal sesuai dengan karakter genetiknya. Dengan demikian perbedaan antar varietas mulai nampak terutama pada pertumbuhan tinggi tanaman. Pemanenan pada umur tanaman 70 hst menghasilkan kadar protein kasar dalam brangkasan yang lebih tinggi dibandingkan dengan umur 50 maupun 90 hst (Koten et al. 2012).

\section{Hasil dan komponen hasil tiga varietas sorgum manis pada jarak tanam yang berbeda}

Gambar 1 menunjukkan bobot brangkasan tertinggi diperoleh pada jarak tanam 70×10 $\mathrm{cm}$ sebesar 15,19 ton/ha dan berbeda tidak nyata dengan jarak tanam $60 \times 10 \mathrm{~cm}$ dan $70 \times 15$ $\mathrm{cm}$ yang menghasilkan bobot panen brangkasan 13,26 dan 13 ton/ha. Hal ini memperlihatkan populasi tanaman yang lebih padat dengan menambah kerapatan tanaman dalam barisan, namun tetap membuka kanopi tanaman untuk penetrasi cahaya matahari yang optimal lebih ideal untuk diterapkan pada budidaya sorgum manis dengan tujuan dipanen brangkasan untuk hijauan alternatif yang dapat dipilih untuk menghasilkan panen 
Tabel 1. Kuadrat tengah hasil dan komponen agronomis sorgum manis pada beberapa tingkat jumlah populasi

\begin{tabular}{|c|c|c|c|c|c|c|c|}
\hline Sumber keragaman & Varietas & Populasi & $\begin{array}{l}\text { Varietas: } \\
\text { Populasi* }\end{array}$ & Eror (b) & $\mathrm{CVa}$ & $\mathrm{CVb}$ & Mean \\
\hline DF & 2 & 5 & 10 & 30 & & & \\
\hline \multicolumn{8}{|l|}{ Komponen hasil } \\
\hline Brangkasan & $16,56^{\mathrm{tn}}$ & $65,42^{* *}$ & $4,29^{\mathrm{tn}}$ & 11,92 & 28,8 & 30,1 & 11,5 \\
\hline Batang & $6,65^{\text {tn }}$ & $16,38^{* *}$ & $0,74^{\text {tn }}$ & 2,58 & 24,8 & 23,9 & 6,71 \\
\hline Kadar brix & $13,88^{*}$ & $0,44^{\text {tn }}$ & $0,35^{\mathrm{tn}}$ & 0,65 & 20,5 & 17,3 & 4,67 \\
\hline Alkohol & $68,37^{* *}$ & $2,12^{\mathrm{tn}}$ & $1,32^{\mathrm{tn}}$ & 4,85 & 9,07 & 19,7 & 11,2 \\
\hline Nira & $3.069 .967^{\mathrm{tn}}$ & $338.1018^{* *}$ & $408.660^{\mathrm{tn}}$ & 757.964 & 32,9 & 27,1 & 3213 \\
\hline \multicolumn{8}{|l|}{ Umur 30 hst } \\
\hline Tinggi & $1,48^{\mathrm{tn}}$ & $12,31^{* *}$ & $0,91^{\mathrm{tn}}$ & 3,17 & 13,8 & 11,5 & 15,4 \\
\hline Jumlah daun & $0,13^{\text {tn }}$ & $0,35^{\text {tn }}$ & $0,24^{\mathrm{tn}}$ & 0,20 & 14,7 & 17,4 & 2,6 \\
\hline Panjang daun & $20,14^{\text {tn }}$ & $32,64^{\mathrm{tn}}$ & $12,54^{\mathrm{tn}}$ & 15,66 & 5,58 & 9,52 & 41,6 \\
\hline Lebar daun & $0,54^{\mathrm{tn}}$ & $0,47^{\mathrm{tn}}$ & $0,15^{\mathrm{tn}}$ & 0,22 & 11,5 & 13,3 & 3,56 \\
\hline SPAD & $6,59^{\operatorname{tn}}$ & $8,81^{\mathrm{tn}}$ & $4,31^{\mathrm{tn}}$ & 6,72 & 3,61 & 7,09 & 36,5 \\
\hline Diameter & $0,07^{\mathrm{tn}}$ & $0,02^{\text {tn }}$ & $0,95^{\text {tn }}$ & 1,81 & 13,7 & 12,7 & 10,6 \\
\hline \multicolumn{8}{|l|}{ Umur $50 \mathrm{hst}$} \\
\hline Tinggi & $2.319,54^{\mathrm{tn}}$ & $417,51^{\mathrm{tn}}$ & $200,92^{\text {tn }}$ & 217,12 & 11 & 8,04 & 183 \\
\hline Jumlah daun & $0,28^{\mathrm{tn}}$ & $0,56^{*}$ & $0,13^{\text {tn }}$ & 0,16 & 14,5 & 8,99 & 4,41 \\
\hline Panjang daun & $8,43^{\text {tn }}$ & $13,54^{\mathrm{tn}}$ & $32,36^{\mathrm{tn}}$ & 21,51 & 7,48 & 5,97 & 77,7 \\
\hline Lebar daun & $5,58^{*}$ & $1,12^{* *}$ & $0,20^{\operatorname{tn}}$ & 0,21 & 12,3 & 6,58 & 6,99 \\
\hline SPAD & $12,62^{\mathrm{tn}}$ & $36,08^{* *}$ & $8,37^{\mathrm{tn}}$ & 9,32 & 9 & 7,14 & 42,7 \\
\hline Diameter & $44,29^{*}$ & $15,43^{* *}$ & $1,60^{\mathrm{tn}}$ & 2,33 & 12,5 & 7,97 & 19,1 \\
\hline \multicolumn{8}{|l|}{ Umur 70 hst } \\
\hline Tinggi tanaman & $10.835^{* *}$ & $1.902^{*}$ & $1.057^{\mathrm{tn}}$ & 651,49 & 5,97 & 12,3 & 208 \\
\hline Jumlah daun & $1,26^{\mathrm{tn}}$ & $0,38^{\mathrm{tn}}$ & $0,48^{\mathrm{tn}}$ & 0,57 & 8,58 & 6,21 & 12,1 \\
\hline Panjang daun & $21,77^{\mathrm{tn}}$ & $34,49^{*}$ & $18,18^{\mathrm{tn}}$ & 13,52 & 5,24 & 4,13 & 89,1 \\
\hline Lebar daun & $3,92^{\text {tn }}$ & $9,05^{\text {tn }}$ & $8,51^{\text {tn }}$ & 8,32 & 35,4 & 35,5 & 8,13 \\
\hline Diameter batang & $23,65^{*}$ & $24,69^{* *}$ & $5,06^{\mathrm{tn}}$ & 3,83 & 7,53 & 10,9 & 17,9 \\
\hline Jumlah ruas & $25,83^{* *}$ & $1,81^{\mathrm{tn}}$ & $2,14^{\mathrm{tn}}$ & 1,84 & 9,06 & 14,7 & 9,21 \\
\hline
\end{tabular}

*: Menunjukkan berbeda nyata pada nilai P 5\% uji LSD; **: Menunjukkan berbeda nyata pada nilai P $1 \%$ uji LSD; tn: Menunjukkan tidak berbeda

brangkasan sorgum manis yang maksimal adalah jarak tanam $70 \times 10 \mathrm{~cm}$, jarak tanam $60 \times 10 \mathrm{~cm}$ dan jarak tanam $70 \times 15 \mathrm{~cm}$. Menurut Capriyati et al. (2014), tanaman sorgum merupakan tanaman $\mathrm{C} 4$ yang efisien dalam memanfaatkan cahaya matahari dalam proses fotosintesis.

Semakin lebar jarak antar tanaman sorgum, mengakibatkan populasi tanaman semakin sedikit, pada jarak antar barisan $70 \mathrm{~cm}$ menunjukkan hasil yang semakin rendah dengan semakin meningkatnya jarak antar tanaman. Hasil yang hampir sama juga diperoleh pada jarak antar barisan $60 \mathrm{~cm}$. Sesuai dengan hasil penelitian (Carmi et al. 2006) populasi tanaman tidak berpengaruh pada hasil tanaman sorgum per individu, sehingga pada jarak 
antar barisan yang sama, semakin banyak populasi tanaman, hasil panen juga akan meningkat sampai pada kerapatan tanaman tertentu. Menurut Fernandez et al. (2012) beberapa hasil penelitian menunjukkan secara umum hasil sorgum meningkat seiring dengan peningkatan populasi tanaman.

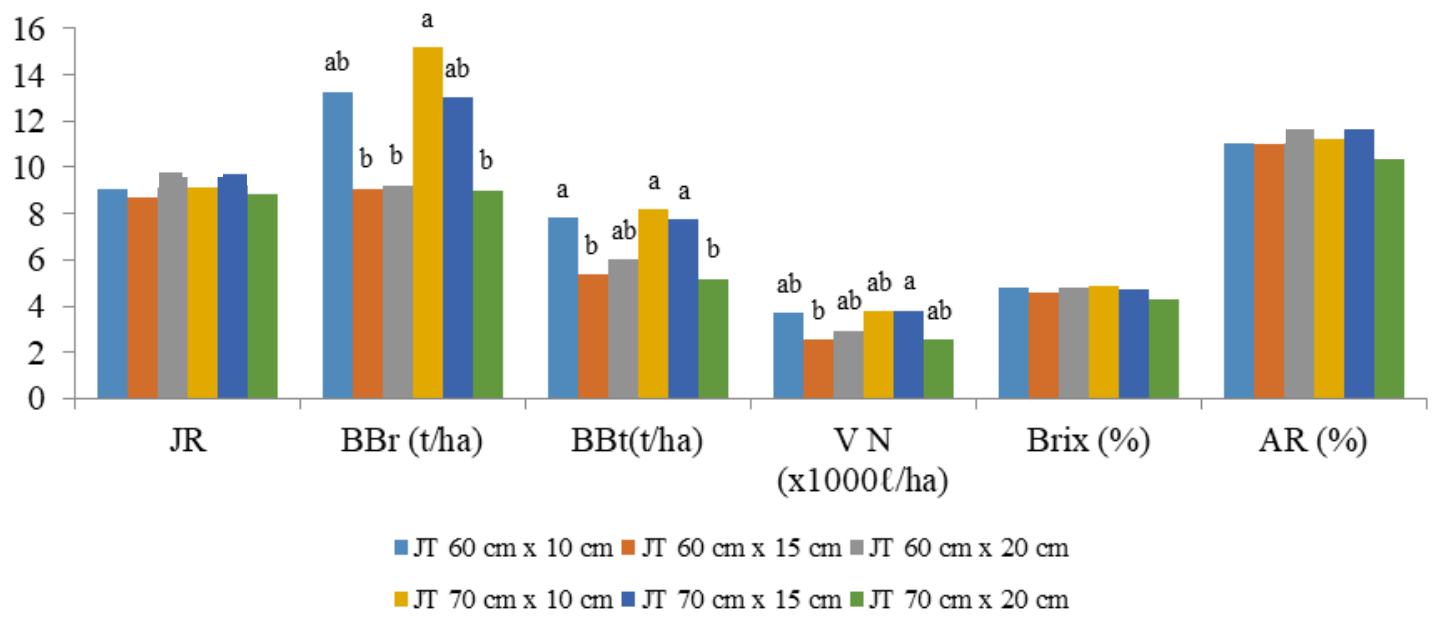

JR: Jumlah ruas; BBr: Bobot brangkasan; BBt: Bobot batang; VN: Volume nira; AR: Alkohol relatif

Gambar 1. Bobot brangkasan dan komponen hasil lainnya panen sorgum manis pada populasi yang berbeda pada umur 70 hst

Varietas sorgum manis tidak berpengaruh nyata terhadap hasil biomassa brangkasan dan jumlah ruas batang maupun volume nira. Namun, pada komponen kadar brix, kadar alkohol relatif, ketiga varietas menunjukkan perbedaan. Varietas Numbu memiliki jumlah ruas rata-rata yang lebih banyak (10,28\%) dibandingkan dengan Super $1(9,42 \%)$ dan Super 2 (7,92\%). Terhadap hasil pengukuran kadar brix, Numbu dan Super 1 memiliki hasil yang lebih tinggi dibandingkan dengan Super 2. Sedangkan terhadap hasil pengukuran kadar alkohol relatif, Numbu memiliki nilai yang paling tinggi $(12,88 \%)$, disusul Super $1(11,58 \%)$ dan nilai paling rendah diperoleh pada varietas Super $2(9,05 \%)$ (Gambar 2).

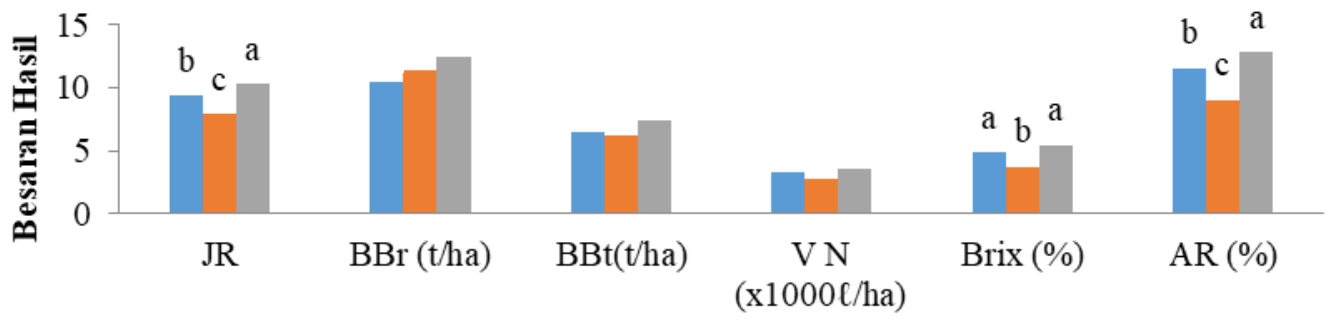

Hasil dan Komponen Hasil Panen

- Super 1 Super 2 Numbu

JR: Jumlah ruas; BBr: Bobot brangkasan; BBt: Bobot batang; VN: Volume nira; AR: Alkohol relatif

Gambar 2. Hasil dan komponen hasil panen tiga varietas sorgum manis pada umur $70 \mathrm{hst}$

Hasil uji bobot brangkasan antar varietas menunjukkan tidak berbeda nyata serta interaksi dengan jarak tanam tidak nyata (Tabel 1). Artinya bobot brangkasan ketiga varietas sama dengan nilai rata-rata yaitu 11,45 ton/ha (Tabel 2) tidak dipengaruhi oleh kepadatan tanaman. Sedangkan jarak tanam berpengaruh sangat nyata terhadap bobot 
brangkasan. Hasil tertinggi diperoleh pada jarak tanam $70 \times 10,60 \times 10$ dan $70 \times 15 \mathrm{~cm}$ dengan hasil 13,26-15,19 ton/ha (Tabel 2 dan Gambar 1).

Tabel 2. Bobot brangkasan tanaman pada populasi tanaman dan tiga varietas sorgum pada umur 70 hst (ton/ha)

\begin{tabular}{|c|c|c|c|c|c|c|c|}
\hline \multirow{2}{*}{ Varietas } & \multicolumn{6}{|c|}{ Jarak tanam } & \multirow{2}{*}{ Rata-rats } \\
\hline & $\mathrm{P} 1$ & $\mathrm{P} 2$ & $\mathrm{P} 3$ & P4 & P5 & P6 & \\
\hline Super 1 & 11,00 & 7,20 & 8,43 & 16,67 & 12,07 & 7,73 & 10,52 \\
\hline Super 2 & 14,30 & 9,03 & 9,53 & 13,97 & 12,93 & 8,70 & 11,41 \\
\hline Numbu & 14,47 & 10,97 & 9,70 & 14,93 & 14,00 & 10,53 & 12,43 \\
\hline Rata-rata & $13,26^{\mathrm{ab}}$ & $9,07^{\mathrm{b}}$ & $9,22^{\mathrm{b}}$ & $15,19^{a}$ & $13,00^{\mathrm{ab}}$ & $8,99^{\mathrm{b}}$ & 11,45 \\
\hline
\end{tabular}

P1: Jarak tanam $60 \times 10 \mathrm{~cm}=166.667$ tanaman/ha; P2: Jarak tanam $60 \times 15 \mathrm{~cm}=111.111$ tanaman/ha; P3: Jarak tanam $60 \times 20 \mathrm{~cm}=83.333$ tanaman/ha; P4: Jarak tanam $70 \times 10 \mathrm{~cm}=$ 142.857 tanaman/ha; P5: Jarak tanam $70 \times 15 \mathrm{~cm}=95.238$ tanaman/ha; dan P6: Jarak tanam 70 $\times 20$ $\mathrm{cm}=71.429$ tanaman/ha

Anandan et al. (2012) menggunakan ampas (bagase) hasil perasan batang sorgum untuk membuat campuran pakan kambing, dengan peningkatan produksi pada kisaran $30 \%$ dibandingkan dengan kontrol. Pemanfaatan bagase meningkatkan nilai ekonomi sorgum dalam produksi bioetanol. Tingginya biaya pakan sering menjadi kendala bagi peternak dalam usaha peningkatan hasil, sehingga jika mampu memanfaatkan bahan pakan yang murah namun berkualitas, maka keuntungan yang layak dapat diperoleh dari usaha tersebut (Baba et al. 2011). Pertimbangan pemilihan varietas sorgum sebagai bahan pakan terkait pengaruhnya terhadap produktivitas ternak (Zerbini et al. 2003) karena terdapat perbedaan signifikan pada kandungan N, lignin dan asam fenolik (Zerbini et al. 2002).

\section{Korelasi hasil brangkasan dengan komponen hasil dan karakter agronomis}

Panjang daun 70 hst, jumlah ruas 70 hst dan tinggi tanaman 50 hst nyata menunjukkan adanya korelasi positif dengan bobot brangkasan tanaman, dengan nilai $\mathrm{r}$ berkisar antara 0,29-0,34. Bobot brangkasan per hektar dengan bobot batang, volume nira dan diameter batang 30 hst sangat nyata berkorelasi positif (Tabel 3). Korelasi antar karakter agronomis yang sangat nyata dan memiliki nilai positif yang tinggi adalah antara volume nira dengan jumlah ruas 70 hst dan dengan bobot batang per ha dengan nilai masing-masing 0,61 dan 0,88 . Korelasi yang tinggi menunjukkan hubungan saling mempengaruhi yang kuat antar karakter (Santoso et al. 2014).

Tabel 3. Korelasi bobot brangkasan dengan karakter agronomis lainnya

\begin{tabular}{lcccccc}
\hline \hline Karakter agronomis & $\begin{array}{c}\text { Bobot } \\
\text { brangkasan }\end{array}$ & $\begin{array}{c}\text { Panjang } \\
\text { daun 70 }\end{array}$ & $\begin{array}{c}\text { Jumlah } \\
\text { ruas 70 }\end{array}$ & $\begin{array}{c}\text { Bobot } \\
\text { batang/ha }\end{array}$ & Nira & $\begin{array}{c}\text { Diameter } \\
30\end{array}$ \\
\hline Panjang daun 70 hst & $0,29^{*}$ & & & & & \\
Jumlah ruas 70 hst & $0,34^{*}$ & $0,29^{*}$ & & & & \\
Bobot batang/ha & $0,89^{* *}$ & $0,36^{* *}$ & $0,50^{* *}$ & & & \\
Volume nira & $0,78^{* *}$ & $0,34^{*}$ & $0,61^{* *}$ & $0,88^{* *}$ & & \\
Diameter 30 hst & $0,37^{* *}$ & $0,16^{\text {tn }}$ & $0,18^{\text {tn }}$ & $0,25^{\text {tn }}$ & $0,23^{\text {tn }}$ & \\
Tinggi 50 hst & $0,30^{*}$ & $0,33^{*}$ & $0,58^{* *}$ & $0,45^{* *}$ & $0,57^{* *}$ & $0,22^{\text {tn }}$ \\
\hline
\end{tabular}

**: Menunjukkan berbeda nyata pada nilai P $1 \%$ uji LSD; *: Menunjukkan berbeda nyata pada nilai P 5\% uji LSD; tn: Menunjukkan tidak berbeda; 30, 50 dan 70: Menunjukkan umur tanaman (hst) 
Pemanfaatan brangkasan sorgum manis sebagai bahan pakan ternak besar maupun sedang merupakan salah satu alternatif yang dapat dikembangkan terutama untuk mengisi lahan-lahan suboptimal, mengingat sorgum memiliki daya adaptasi yang cukup tinggi pada lahan marjinal (Agung et al. 2013). Selain itu, sorgum manis memiliki produktivitas brangkasan yang cukup tinggi perluasan lahan dan dapat diratun (Tsuchihashi \& Goto 2008) sehingga mampu mencukupi kebutuhan pakan ternak tanpa melakukan penanaman berulang ulang. Peningkatan populasi tanaman pada jarak tanam $70 \mathrm{~cm}$ dengan kerapatan tanaman hingga $10 \mathrm{~cm}$ mampu meningkatkan produktivitas biomassa brangkasan sorgum manis karena tidak mengurangi hasil per individu tanaman.

\section{KESIMPULAN}

Populasi yang tinggi pada tanaman sorgum sampai pada jumlah tertentu meningkatkan hasil brangkasan dan batang sorgum. Hasil panen brangkasan tertinggi pada saat tanaman

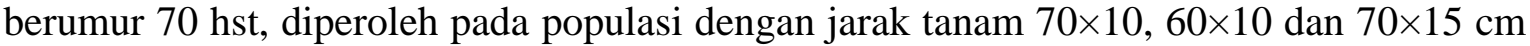
untuk semua varietas dengan nilai berkisar dari 13,00-15,19 ton/ha. Bobot brangkasan berkorelasi sangat nyata dengan bobot batang per ha $(r=0,89)$, volume nira $(r=0,78)$ dan diameter batang 30 hst $(\mathrm{r}=0,37)$.

\section{DAFTAR PUSTAKA}

Abqoriyah, Utomo R, Suwignyo. 2015. Produktivitas tanaman kaliandra (Calliandra calothyrsus) sebagai hijauan pakan pada umur pemotongan yang berbeda. Buletin Peternakan. 39:103-108.

Agung I, Sardiana I, Diara IW, Nurjaya IGMON. 2013. Adaptation, biomass and ethanol yields of sweet sorghum (Sorghum bicolor (L) Moench) varieties at dryland farming areas of Jimbaran Bali, Indonesia. J Biol Agric Healthc. 3:110-115.

Anandan S, Zoltan H, Khan AA, Ravi D, Blümmel M. 2012. Feeding value of sweet sorghum bagasse and leaf residues after juice extraction for bio-ethanol production fed to sheep as complete rations in diverse physical forms. Anim Feed Sci Technol. 175:131-136.

Andrzejewski B, Eggleston G, Powell R. 2013. Pilot plant clarification of sweet sorghum juice and evaporation of raw and clarified juices. Ind Crops Prod. 49:648-658.

Baba S, Muktiani A, Ako A, Dagong MI. 2011. Keragaman dan kebutuhan teknologi pakan peternak sapi perah di Kabupaten Enrekang. Media Peternakan. 34:146-154.

Barbanti L, Grandi S, Vecchi A, Venturi G. 2006. Sweet and fibre sorghum (Sorghum bicolor (L) Moench), energy crops in the frame of environmental protection from excessive nitrogen loads. Eur J Agron. 25:30-39.

Barcelos CA, Maeda RN, Santa Anna LMM, Pereira N. 2016. Sweet sorghum as a whole-crop feedstock for ethanol production. Biomass Bioenergy. 94:46-56.

Berenguer MJ, Faci JM. 2001. Sorghum (Sorghum bicolor L-Moench) yield compensation processes under different plant densities and variable water supply. Eur J Agron. 15:43-55.

Borghi E, Crusciol CAC, Nascente AS, Sousa VV, Martins PO, Mateus GP, Costa C. 2013. Sorghum grain yield, forage biomass production and revenue as affected by intercropping time. Eur J Agron. 51:130-139.

Capriyati R, Tohan, Kastono D. 2014. Pengaruh jarak tanam dama tumpangsari sorgum manis (Sorghum bicolor L Moench) dan dua habitus wijen (Sesamum inicum L) terhadap pertumbuhan dan hasil. Vegetalika. 3:49-62.

Carmi A, Aharoni Y, Edelstein M, Umiel N, Hagiladi A, Yosef E, Nikbachat M, Zenou A, Miron J. 2006. Effects of irrigation and plant density on yield, composition and in vitro digestibility 
of a new forage sorghum variety, Tal, at two maturity stages. Anim Feed Sci Technol. 131:121-133.

Enciso J, Jifon J, Ribera L, Zapata SD, Ganjegunte GK. 2015. Yield, water use efficiency and economic analysis of energy sorghum in South Texas. Biomass Bioenergy. 81:339-344.

Fernandez CJ, Fromme DD, Grichar WJ. 2012. Grain sorghum response to row spacing and plant populations in the Texas Coastal Bend Region. Int J Agron. 2012:14-19.

Haryanto B. 2009. Inovasi teknologi pakan ternak dalam sistem integrasi tanaman-ternak bebas limbah mendukung upaya peningkatan produksi daging. Pengembangan Inovasi Pertanian. 2:163-176.

Irawan B, Sutrisna N. 2011. Prospek pengembangan sorgum di Jawa Barat mendukung diversivikasi pangan. Forum Penelit Agro Ekonomi. 29:99-113.

Koten BB, Soetrisno RD, Ngadiyono N, Suwignyo B. 2012. Produksi tanaman sorgum (Sorghum bicolor (L) Moench) varietas lokal rote sebagai hijauan oakan ruminansia pada umur panen dan dosis pupuk urea yang berbeda. Buletin Peternakan. 36:150-155.

Pusdatin. 2017. Basis data statistik pertanian. Jakarta (Indonesia): Pusat Data dan Informasi, Kementerian Pertanian.

Santoso SB, Yasin M, Faesal H. 2014. Daya gabung inbreed jagung pulut untuk pembentukan varietas hibrida. Penelitian Pertanian Tanaman Pangan. 33:155-162.

Sirappa MP. 2003. Prospek pengembangan sorgum di Indonesia sebagai komoditas alternatif untuk uangan, pakan, dan industri. J Litbang Pertanian. 22:133-140.

Sudirman, Suhubdy, Hasan SD, Dilaga SH, Karda IW. 2015. Kandungan neutral detergent fibre (NDF) dan acid detergent fibre (ADF) bahan pakan lokal ternak sapi yang dipelihara pada kandang kelompok. J Ilmu Teknologi Peternakan Indonesia. 1:66-70.

Tsuchihashi N, Goto Y. 2008. Year-round cultivation of sweet sorghum (Sorghum bicolor (L) Moench) through a combination of seed and ratoon cropping in Indonesian Savanna. Plant Prod Sci. 11:377-384.

Yu J, Zhang T, Zhong J, Zhang X, Tan T. 2012. Biorefinery of sweet sorghum stem. Biotechnol Adv. 30:811-816.

Zerbini E, Krishan CT, Victor XVA, Sharma A. 2002. Composition and in vitro gas production of whole stems and cell walls of different genotypes of pearl millet and sorghum. Anim Feed Sci Technol. 98:73-85.

Zerbini E, Reddy BVS, Hash CT, Bidinger F, Khan AA. 2003. Improving the production and utilization of sorghum and pearl millet as livestock feed: Progress towards dual-purpose genotypes. F Crop Res. 84:143-158.

\section{DISKUSI}

\section{Pertanyaan}

1. Apakah penelitian ini satu paket dengan Ibu Syuryawati? Jika benar, mengapa pada kesimpulan Ibu Syuryawati jarak tanam $60 x 10 \mathrm{~cm}$ merupakan populasi terbaik sedangkan dalam penelitian ini jarak tanam $70 \times 20 \mathrm{~cm}$ merupakan populasi terbaik?

2. Sorgum manis, kenapa disebut sebagai "sorgum manis" apa perbedaannya dengan sorgum lainnya (apakah ada sorgum tidak manis)?

\section{Tambahkan potensi biji sorgum sebagai bahan pakan unggas di pendahuluan}




\section{Jawaban}

1. Benar, penelitian ini satu paket dengan penelitian Ibu Syuryawati, namun dengan sudut pandang berbeda, pengambilan data yang berbeda dan umur tanaman yang diamati juga berbeda. Ibu Syuryawati lebih mengamati sisi ekonominya, sedangkan penelitian ini menitikberatkan pada kondisi agronomisnya. Pengambilan sampel data pada penelitian ini dilaksanakan pada 30-50 hst dan 70 hst pada saat tanaman masih muda, sedangkan pada penelitian Ibu Syuryawati pengambilan sampel data dilakukan pada umur tanaman 110 hst pada kondisi tanaman telah memasuki umur masak fisiologis sehingga potensi genetisnya telah optimal yang mengakibatkan perbedaan hasil. Pemanenan sampel pada penelitian ini dilaksanakan pada umur 70 hst dengan pertimbangan seluruh bagian tanaman masih dapat langsung dipergunakan sebagai hijauan pakan tanpa pengolahan lebih lanjut serta memiliki kandungan gizi yang masih tinggi dan serat yang memiliki nilai NDF rendah. Perbedaan umur tanaman saat pengambilan sampel sangat mempengaruhi hasil panen brangkasan.

2. Sorgum manis (Sorghum bicolor (L) Moench) disebut sebagai sorgum manis karena memiliki kandungan karbohidrat terlarut (glukosa dan sukrosa) serta karbohidrat tak larut (selulosa dan hemiselulosa) yang seimbang sehingga memiliki rasa yang manis terutama pada batangnya dan bagian tanaman lainnya (nilai brix bisa mencapai 18\%). Contoh varietas sorgum manis: Super 1, Super 2 dan Numbu. Varietas sorgum tidak manis salah satu varietasnya yaitu Kawali.

3. Saran penambahan pustaka di pendahuluan mengenai potensi biji sorgum telah ditambahkan pada pendahuluan. 